\title{
Sectoral Nonlinear Causality Between Stock Market Volatility and the COVID-19 Pandemic: Evidence From India
}

\author{
Debi Bal $^{1}$, Seba Mohanty ${ }^{1}$ \\ ${ }^{1}$ Department of Economics, Birla School of Social Sciences \&Humanities, Birla Global University Bhubaneswar, India \\ Keywords: covid-19, volatility, stock market \\ $10.46557 / 001 c .21380$
}

\section{Asian Economics Letters}

Vol. 2, Issue 1, 2021

\begin{abstract}
This paper examines the linear and nonlinear relationship between daily confirmed COVID-19 cases and sectoral stock market volatility in India. The linear Granger causality test reveals bidirectional causality. Further, we observe that bidirectional nonlinear Granger causality exists between stock market volatility and COVID-19. This implies that the historical and lagged information can have a significant role in predicting COVID-19 cases and the stock market.
\end{abstract}

\section{Introduction}

In this paper, we examine the nonlinear relationship between sectoral stock market volatility and COVID-19 in India. Our hypothesis is that any lagged information affects the stock market volatility during the COVID-19 period. The proposed relationship is important because the outbreak of COVID-19 has affected economies globally. This pandemic has created an unprecedented global shock, resulting in an increase in financial market volatility. To mitigate the repercussions of the crisis, India adopted lockdown and self-isolation measures. These measures negatively impacted economic activities, thus creating market uncertainties. This is a feature we observe from the Indian financial market.

We use a GARCH model to measure the volatility. In the next step, we use the Diks \& Panchenko (2006) nonlinear Granger causality test. We find that there exists a bidirectional nonlinear causality between the volatilities of oil and gas, metal, movable consumer goods, and health care to the growth rate of COVID-19.

Our findings contribute to the literature in three ways. First, we divide the stock market into sectors, such as oil and gas, metal, fast movable consumer goods and health care, and measure their sectoral stock return volatility. This sectorial analysis is important because it help trace the individual stock market volatility due to COVID-19 cases. Second, India is the second highest COVID-19 affected country after the USA. From an emerging market perspective, it is worthwhile examining the relation between the growth rate of confirmed daily virus cases and sectorial stock market. This type of analysis has not been undertaken, therefore, there is limited knowledge of sectorial return volatility and COVID-19. For some recent literature, see Al-Awadhi et al. (2020), Alfaro et al. (2020), Ashraf (2020), Baker et al. (2020), Haroon \& Rizvi (2020), and Iyke (2020).

\section{Data and Methodology}

We have used the daily data on COVID - 19 confirmed cases and sector level indices of Indian stock market. These include oil and gas, metal, fast moving consumer goods, and health care. The daily data cover the period March 3, 2020 to October 8, 2020. The sample period of the study falls in the COVID-19 period. The daily COVID-19 confirmed cases data are collected from the COVID19INDIA database published by the government of India ${ }^{1}$. The data set of the sectoral stock market index is collected from the CEIC database. We have converted our daily COVID-19 case data into logarithmic from which shows the growth rate of confirmed cases on COVID-19. We have taken the return of the stock market and it is calculated as the log of current price divided by previous price, multiplied with 100 .

In the next step, we measure the volatility of sectoral stock market index by using a GARCH $(1,1)$ model. Since the method is well known, we do not repeat it here. In the next step, we use both the linear Granger causality and the Diks \& Panchenko (2006) nonlinear Granger causality tests.

\section{Main Findings}

We begin with the results of summary statistics such as mean, median, standard deviation, skewness, maximum and minimum values which are presented in Table 1 . The results show that the mean of the COVID-19 confirmed cases are 28243 and the growth rate of COVID-19 (LCOVID-19) case is 8.78 per day. The standard deviation of the growth rate of COVID-19 is excessive during this period. The varia-

\footnotetext{
a Corresponding author email: mohanty.seba@gmail.com
}

1 https://www.covid19india.org/ 
Table 1: Descriptive statistics, unit root, and nonlinear Granger causality test results

\begin{tabular}{|c|c|c|c|c|c|c|}
\hline \multicolumn{7}{|c|}{ Panel A: Descriptive statistics of COVID-19 confirmed cases and volatility of stock return } \\
\hline Variable & Mean & Median & $\begin{array}{l}\text { Standard } \\
\text { deviation }\end{array}$ & Maximum & Minimum & Skewness \\
\hline LCOVID-19 & 8.78 & 9.7 & 2.89 & 11.49 & 0.00 & -1.39 \\
\hline VOLOG & 6.18 & 3.1 & 9.18 & 64.52 & 1.05 & 3.35 \\
\hline VOLM & 8.17 & 1.32 & 5.86 & 35.19 & 0.62 & 2.91 \\
\hline VOLMC & 6.02 & 3.52 & 6.69 & 35.3 & 0.67 & 2.33 \\
\hline VOLHC & 4.12 & 2.1 & 5.48 & 37.5 & 1.05 & 3.69 \\
\hline COVID-19 & 28243 & 10559 & 32596.92 & 97860 & 1.00 & 0.78 \\
\hline \multicolumn{7}{|c|}{ Panel B: Narayan and Popp (2010) unit root test results } \\
\hline $\begin{array}{l}\text { Break in Trend \& } \\
\text { Intercept }\end{array}$ & $t$-value & $\begin{array}{l}\text { First } \\
\text { break }\end{array}$ & Second break & $\phi$ & & Lag length \\
\hline LCOVID-19 & -0.8539 & $\begin{array}{c}23 / 03 / \\
2020\end{array}$ & $15 / 04 / 2020$ & -0.047 & & 4 \\
\hline VOLOG & -4.364 & $\begin{array}{c}24 / 03 / \\
2020\end{array}$ & $26 / 03 / 2020$ & -0.2643 & & 5 \\
\hline VOLM & -4.293 & $\begin{array}{c}23 / 03 / \\
2020\end{array}$ & $17 / 04 / 2020$ & -0.2492 & & 3 \\
\hline VOLMC & -4.412 & $\begin{array}{c}26 / 03 / \\
2020\end{array}$ & $31 / 03 / 2020$ & -0.2102 & & 5 \\
\hline VOLHC & -4.985 & $\begin{array}{c}20 / 03 / \\
2020\end{array}$ & $31 / 03 / 2020$ & -0.493 & & 5 \\
\hline \multicolumn{7}{|c|}{ Panel C: Nonlinear causality test results } \\
\hline & F-statistic & \multicolumn{4}{|c|}{$D \& P(2006)$ nonlinear causality ( $t$-test) } & Inference \\
\hline Lag/Null Hypothesis & & 2 & 3 & 4 & 5 & \\
\hline $\begin{array}{l}\text { LCOVID-19 CAUSES } \\
\text { VOLOG }\end{array}$ & $\begin{array}{l}7.51^{* * *} \\
(0.00)\end{array}$ & $\begin{array}{l}2.38^{* * *} \\
(0.00)\end{array}$ & $2.06^{* * *}(0.01)$ & $\begin{array}{l}1.75^{* *} \\
(0.03)\end{array}$ & $\begin{array}{l}1.33^{*} \\
(0.09)\end{array}$ & Reject \\
\hline $\begin{array}{l}\text { VOLOG CAUSES } \\
\text { LCOVID-19 }\end{array}$ & $\begin{array}{l}7.16^{* * *} \\
(0.00)\end{array}$ & $\begin{array}{l}3.08^{* * *} \\
(0.00)\end{array}$ & $2.47^{* * *}(0.00)$ & $\begin{array}{l}5.08^{* * *} \\
(0.00)\end{array}$ & $\begin{array}{l}1.58^{* *} \\
(0.05)\end{array}$ & Reject \\
\hline $\begin{array}{l}\text { LCOVID-19 CAUSES } \\
\text { VOLM }\end{array}$ & $\begin{array}{l}7.08^{* * *} \\
(0.00)\end{array}$ & $\begin{array}{l}2.16^{* * *} \\
(0.01)\end{array}$ & $2.01^{* *}(0.02)$ & $\begin{array}{l}1.65^{* *} \\
(0.04)\end{array}$ & $\begin{array}{l}1.23^{*} \\
(0.10)\end{array}$ & Reject \\
\hline $\begin{array}{l}\text { VOLM CAUSES } \\
\text { LCOVID-19 }\end{array}$ & $\begin{array}{l}6.84^{* * *} \\
(0.00)\end{array}$ & $1.20(0.11)$ & $1.11(0.13)$ & $1.11(0.13)$ & $\begin{array}{c}0.59 \\
(0.27)\end{array}$ & Not Reject \\
\hline $\begin{array}{l}\text { LCOVID-19 CAUSES } \\
\text { VOLMC }\end{array}$ & $\begin{array}{l}3.54^{* * *} \\
(0.00)\end{array}$ & $\begin{array}{l}3.22^{* * *} \\
(0.00)\end{array}$ & $2.66^{* * *}(0.00)$ & $\begin{array}{l}2.22^{* * *} \\
(0.01)\end{array}$ & $\begin{array}{l}1.87^{* *} \\
(0.03)\end{array}$ & Reject \\
\hline $\begin{array}{l}\text { VOLMC CAUSES } \\
\text { LCOVID-19 }\end{array}$ & $\begin{array}{l}3.79^{* * *} \\
(0.00)\end{array}$ & $\begin{array}{l}1.50^{*} \\
(0.06)\end{array}$ & $0.65(0.25)$ & $\begin{array}{l}1.72^{* *} \\
(0.04)\end{array}$ & $\begin{array}{l}1.60^{* *} \\
(0.05)\end{array}$ & Reject \\
\hline $\begin{array}{l}\text { LCOVID-19CAUSES } \\
\text { VOLHC }\end{array}$ & $\begin{array}{l}3.89^{* * *} \\
(0.00)\end{array}$ & $\begin{array}{l}1.70^{* *} \\
(0.04)\end{array}$ & $1.10(0.14)$ & $0.18(0.43)$ & $\begin{array}{c}0.17 \\
(0.43)\end{array}$ & $\begin{array}{l}\text { Weakly } \\
\text { Reject }\end{array}$ \\
\hline $\begin{array}{l}\text { VOLHCCAUSES } \\
\text { LCOVID-19 }\end{array}$ & $0.86(0.46)$ & $\begin{array}{l}1.89^{* *} \\
(0.03)\end{array}$ & $1.21(0.11)$ & $0.78(0.22)$ & $\begin{array}{c}0.33 \\
(0.37)\end{array}$ & $\begin{array}{l}\text { Weakly } \\
\text { Reject }\end{array}$ \\
\hline
\end{tabular}

This table reports the descriptive statistics (Panel A), the Narayan \& Popp (2010) unit root test results (Panel B), and the nonlinear Granger causality test results (Panel C). $p$-values are in the parentheses. ${ }^{* * * * * *}$, and $*$ are the significance levels at $1 \%, 5 \%$, and $10 \%$, respectively.

tion in the volatility of oil and gas (VOLOG) is higher than the variation in the volatility of metal (VOLM), volatility of moveable consumer goods (VOLMC) and the volatility of health care (VOLHC). In the next step, we apply the Narayan \& Popp (2010) unit root test and find mixed results: LCOVID-19, VOLOG, VOLHC are stationary at the level form while $V O L M$ and $V O L M C$ are stationary in first difference. Once we confirmed the stationarity property of the time series variables, we conduct the liner Granger causality test. Further, as the VOLM and VOLMC are I(1) processes, we extract the residuals by using the autoregressive distributed lag (ARDL) model and apply the Diks \& Panchenko (2006) test for causality among the variables (i.e. COVID-19, VOLM, and VOLMC).

The results show that there exists a bidirectional linear causality between VOLOG, VOLM, VOLMC and VOLHC to the growth rate of COVID-19. This implies that as the confirmed cases increase, they cause the sectoral price return volatility to increase. Furthermore, the sectoral return volatility is also causing the growth rate of COVID-19. Given that the confirmed cases of COVID-19 are increasing exponentially, we therefore check for any nonlinear dependency 
among the variables. The results confirm that there exists an independent nonlinear dependency. So, we further analyze the nonlinear causality between the sectoral volatilities of the Indian stock market and the growth rate of COVID-19 by using the Diks \& Panchenko (2006) method. The results are presented in Table 1.

The results confirm that there exists nonlinear causality between the sectoral volatilities of the stock market and the growth rate of COVID-19 cases. We find that there is bidirectional non-linear Granger causality between VOLOG and the growth rate of COVID-19. It implies that the lagged information of COVID-19 cases causes the volatility on the VOLOG. As the confirmed case rises it creates a negative sentiment, which causes the VOLOG. Furthermore, as the country is in the lockdown situation and hence the usage of oil and gas is less compared to the pre-pandemic period, there are fluctuations in oil price/demand and hence the oil market is uncertain. Similarly, the growth rate of cases is more which causes VOLOG. This implies that the investors are investing in safe heaven assets.

Similarly, we find bidirectional nonlinear causality between volatility in the metal sector and the growth rate of the COVID-19 cases. Furthermore, our results show that the growth rate of cases on COVID-19 causes VOLMC. It is because of complete lockdown of the fast-moving consumer goods sector. Finally, the existence of nonlinear causality between COVID-19 and VOLHC cannot be fully ignored. This indicates that the lagged information does have some role in influencing the VOLHC. To examine the robustness of our results, we applied the Diks \& Panchenko (2006) nonlinear causality test to the GARCH model's residuals. The results are not reported here but are available upon request. Overall, the results are not sensitive and are consistent.

\section{Conclusion}

This paper was about exploring the causality relation between the growth rate of COVID-19 cases and India's sectoral stock market returns. Using a range of econometric tools, we conclude that there exists both linear and nonlinear bidirectional causality between the growth rate of COVID-19 daily cases and the volatility of sectoral stock market returns. This implies that the lagged information of the daily COVID-19 confirmed cases and the volatility of sectoral stock market returns can be very helpful in predicting each other in case of India at least in the short-run.

Submitted: January 02, 2021 AEDT, Accepted: February 22, 2021 AEDT 


\section{REFERENCES}

Al-Awadhi, A. M., Al-Saifi, K., Al-Awadhi, A., \& Alhamadi, S. (2020). Death and contagious infectious diseases: Impact of the COVID-19 virus on stock market returns. Journal of Behavioral and Experimental Finance, 27, 100326. https://doi.org/10.1016/j.jbef.202 $\underline{0.100326}$

Alfaro, L., Chari, A., Greenland, A. N., \& Schott, P. K. (2020). Aggregate and firm-level stock returns during pandemics, in real time (No. w26950). National Bureau of Economic Research.

Ashraf, B. N. (2020). Stock markets' reaction to COVID-19: Cases or fatalities? Research in International Business and Finance, 54, 101249. http s://doi.org/10.1016/i.ribaf.2020.101249

Baker, S. R., Bloom, N., Davis, S. J., Kost, K. J., Sammon, M. C., \& Viratyosin, T. (2020). The unprecedented stock market impact of COVID-19 (No. w26945). National Bureau of Economic Research.
Diks, C., \& Panchenko, V. (2006). A new statistic and practical guidelines for nonparametric Granger causality testing. Journal of Economic Dynamics and Control, 30(9-10), 1647-1669. https://doi.org/10.101 6/j.jedc.2005.08.008

Haroon, O., \& Rizvi, S. A. R. (2020). COVID-19: Media coverage and financial markets behavior-A sectoral inquiry. Journal of Behavioral and Experimental Finance, 27, 100343. https://doi.org/10.1016/j.jbef.202 0.100343

Iyke, B. N. (2020). COVID-19: The reaction of US oil and gas producers to the pandemic. Energy Research Letters, 1(2), 13912. https://doi.org/10.46557/001c.13 $\underline{912}$

Narayan, P. K., \& Popp, S. (2010). A new unit root test with two structural breaks in level and slope at unknown time. Journal of Applied Statistics, 37(9), 1425-1438. https://doi.org/10.1080/02664760903039 883 